\title{
GAMBARAN LATAR BELAKANG KELUARGA KORBAN KEKERASAN SEKSUAL DI KABUPATEN SIAK SRI INDRAPURA
}

\author{
${ }^{1}$ Irvan Zuhdi, ${ }^{2}$ Yanwar Arief \\ ${ }^{12}$ Fakultas Psikologi, Universitas Islam Riau, Indonesia. \\ ${ }^{1}$ Corresponding Author: irfanzuhdi5@gmail.com
}

\begin{abstract}
Sexual violence against children is an act related to sexual activity committed by adults against children which can harm the child and provide a threat to the child so that the child is forced to comply with the wishes of the perpetrator of the crime. This research is a quantitative descriptive study that aims to explain or factually describe the topic of the study. This study aims to describe the family background of victims of sexual violence. The data collection method in this study used a questionnaire in the form of several questions containing the research objectives. The sample of the study was 52 parents whose children experienced sexual violence or harassment. The results of the study describe the family background of victims of sexual violence in this study, namely those from families with low economic levels, and negligence of parents towards their children, namely in the form of lack of supervision and lack of closeness (interaction) between parents and children.
\end{abstract}

Keywords: children, family, sexual violence.

\begin{abstract}
ABSTRAK
Kekerasan seksual pada anak merupakan suatu tindakan yang berhubungan dengan aktivitas seksual yang dilakukan oleh orang dewasa terhadap anak-anak yang dapat merugikan anak dan memberikan sebuah ancaman terhadap anak sehingga anak terpaksa untuk menuruti keinginan pelaku kejahatan. Penelitian ini merupakan penelitian deskriptif kuantitatif yang bertujuan untuk menjelaskan atau menggambarkan secara faktual topik dari penelitian. Penelitian ini bertujuan untuk menggambarkan latar belakang keluarga korban kekerasan seksual. Metode pengumpulan data pada penelitian ini menggunakan angket yaitu berupa beberapa pertanyaan yang berisi tentang tujuan penelitian. Sampel penelitian sebanyak 52 orang tua yang anaknya mengalami kekerasan atau pelecehan seksual. Hasil penelitian menggambarkan latar belakang keluarga korban kekerasan seksual pada penelitian ini ialah berasal dari keluarga dengan tingkat ekonomi yang rendah, dan kelalaian orang tua terhadap anaknya yaitu berupa kurangnya pengawasan dan kurangnya kedekatan (interaksi) orang tua dengan anak.
\end{abstract}

Kata kunci: anak, kekerasan seksual, keluarga.

\section{PENDAHULUAN}

Kekerasan terhadap anak di Indonesia selalu terjadi peningkatan setiap tahunnya. Berdasarkan data dari komisi perlindungan anak Indonesia (KPAI) memaparkan data kasus kekerasan terhadap anak dari tahun 2015 sampai dengan tahun 2019. Pada tahun 2015 terjadi sekitar 4.309 kasus terlapor, kemudian pada tahun 2016 terjadi sekitar 4.622 kasus, lalu pada tahun 2017 terjadi sekitar 4.579 kasus, selanjutnya pada tahun 2018 terjadi sekitar 4.885 kasus, dan pada tahun 2019 terhitung dari Januari hingga April terdapat 1.192 kasus kekerasan yang diterima oleh KPAI. (Setiawan, 2019). 
Dari beberapa kasus yang terlapor pada tahun 2018, KPAl mendapati kasus yang berada diurutan teratas yaitu kasus anak berhadapan dengan hukum $(\mathrm{ABH})$ mencapai 1.434 kasus. Sepanjang tahun 2018, kasus anak berhadapan dengan hukum $(\mathrm{ABH})$ didominasi oleh kasus kekerasan seksual yang mana korban didominasi oleh anak perempuan (Setiawan, 2019).

Berikutnya, khusus di provinsi Riau juga mengalami hal yang sama dengan daerah lainnya. UPT P2TP2A Provinsi Riau menangani beberapa kasus kekerasan seksual, berikut adalah rekap penanganan kasus kekerasan seksual terhadap anak tercatat pada tahun 2015 sebanyak 32 kasus, lalu pada tahun 2016 sebanyak 37 kasus, kemudian pada tahun 2017 sebanyak 52 kasus dan pada tahun 2018 merupakan rekap terbanyak dengan jumlah sekitar 74 kasus. Untuk update terbaru data kekerasan seksual di Provinsi Riau pada tahun 2019 yang diperoleh dari UPT P2TP2A Provinsi Riau terjadi sebanyak 53 kasus kekerasan seksual terhadap anak. Berdasarkan dari data tersebut terlihat bahwa kasus kekerasan seksual di provinsi Riau mengalami peningkatan setiap tahunnya, menurut sarkawi ketua koordinator pemicu terjadinya hal ini secara umum disebabkan oleh terjadinya degradasi moral oleh beberapa anggota masyarakat, yang dipengaruhi juga oleh tayangan pornografi yang dapat diakses kapanpun dan dimanapun. Kasus tersebut berasal dari semua pengaduan dari kabupaten/kota yang ada di provinsi Riau. Data pengaduan tersebut didapat melalui laporan langsung dari keluarga, perantara lembaga seperti LSM, dan dari rujukan kepolisian atau rumah sakit. (UPT P2TP2A Riau, 2019).

Berdasarkan dari data hasil wawancara yang dilakukan dengan guru dan orang tua korban kekerasan seksual di Kecamatan Dayun Kabupaten siak, kekerasan seksual yang terjadi pada anak SD dan anak SMP dilakukan oleh oknum guru SMP dan oknum kepala Sekolah SD. Hal tersebut didasari oleh motif agar pelaku mendapatkan ilmu hitam atau ilmu sulap yang syaratnya ialah melakukan hal yang tidak baik tersebut kepada anak-anak. Anak-anak yang menjadi korban kekerasan seksual pada kasus ini berusia berkisar antara usia 10 hingga 17 tahun, semua anak yang mengalami kekerasan seksual tersebut ialah anak laki-laki. Jumlah korban kekerasan seksual yang terjadi khususnya di SD dan SMP di Kecamatan Dayun ialah 43 orang dan sisanya lagi didapat melalui data yang diterima dari dinas P2TP2A Kabupaten Siak yang berlokasi berbeda-beda di kota siak tersebut.

Jenis kekerasan seksual yang dilakukan oleh oknum guru dan kepala sekolah tersebut bervariasi, ada yang mengusap kemaluan korban, meraba kemaluan, mempelihatkan video porno, hingga menghisap kemaluan korban tersebut. Jenis kekerasan berupa menghisap kemaluan korban dilakukan pelaku kepada 7 orang anak dan sisanya lagi ialah mengusap, meraba, dan mempertontonkan video porno kepada anak-anak. Berdasarkan informasi dari guru olahraga dan orang tua korban, pelaku melancarkan aksi kejahatannya tersebut sudah dilakukan sejak 2018 namun baru terbongkar pada tahun 2019, korban menutupi kasus kekerasan yang dialaminya tersebut karena malu dan adanya ancaman dari pelaku.

Kasus kekerasan seksual terhadap anak ibaratkan seperti fenomena gunung es, hanya sedikit yang bisa terungkap dan sangat banyak yang tidak berhasil terungkap hal tersebut disebabkan oleh anak dan orang tua enggan melaporkan kasus tersebut kepada pihak yang berwenang dikarenakan malu dan menutup diri (Hidayati, 2014).

Kekerasan seksual terhadap anak dapat terjadi oleh beberapa faktor salah satunya ialah keluarga, karena keluarga merupakan sebagai tempat pertama atau lingkungan yang pertama kali yang dikenal oleh anak sehingga keluarga juga sebagai pembentuk pola kepribadian dari seorang anak. Hal tersebut didukung penelitian yang dilakukan oleh Fitriyani (2017) bahwa ada 3 hal yang menyebabkan terjadinya kekerasan seksual dilihat dari latar belakang keluarga yaitu tingkat pendidikan 
orang tua yang rendah hal tersebut berakibat pada kurangnya pengawasan dan pengasuhan terhadap anak sehingga membuka peluang terjadinya kekerasan seksual, selanjutnya ialah pengasuhan permisif dari orang tua yang membentuk kepribadian anak tertutup dan bebas sehingga komunikasi orang tua dan anak tidak terjalin dengan baik dapat meningkatkan peluang kekerasan seksual terjadi, dan yang ketiga ialah kepercayaan sosial yang tinggi akibat kohesi sosial di lingkungan keluarga membuat pengasuhan dan pengawasan terhadap anak menjadi melemah sehingga anak merasa tidak diperhatikan dan ditelantarkan oleh orang tua hal tersebut dapat membuka peluang terjadinya kekerasan seksual terhadap anak.

Dari beberapa penelitian terdahulu, memaparkan bahwa kasus kekerasan seksual dapat dipengaruhi oleh kelalaian orang tua. Hal tersebut didukung oleh pendapat Fuadi (2011) bahwa kelalaian orang tua dapat menyebabkan terjadinya kekerasan seksual terhadap anak karena orang tua kurang memperhatikan tumbuh kembang dan pegaulan anak yang membuka peluang anak menjadi korban kekerasan seksual. Hasil penelitian yang dilakukan oleh Kurniasari (2016) menyatakan bahwa penyebab terjadinya kekerasan seksual berupa eksploitasi seksual terhadap anak adalah status ekonomi keluarga (kemiskinan keluarga) dan disfungsi keluarga. Kemiskinan keluarga dan disfungsi keluarga dapat berupa ketidakmampuan keluarga dalam memenuhi kebutuhan anaknya dan tidak memiliki rasa tanggung jawab terhadap anaknya sehingga hal tersebut berdampak pada anak menjadi putus sekolah dan tidak memiliki kemampuan dalam bekerja dan juga membuat anak memilih untuk berkumpul dengan lingkungan yang tidak baik dan memperkenalkannya pada aktivitas seksual sehingga mendorong anak untuk menjadi penyedia jasa layanan seksual demi memenuhi kebutuhan hidupnya sendiri.

Selanjutnya, penelitian yang dilakukan oleh (Subidia dan Raijaya, 2017) menyatakan bahwa kekerasan seksual pada anak dapat disebabkan oleh faktor sosial ekonomi yang terdiri dari tingkat pendidikan, kemiskinan, media sosial, dan kondisi keluarga. Hasil penelitian yang dilakukan oleh menjelaskan bahwa kasus kekerasan pada anak yang sering terjadi ialah pada masyarakat menengah kebawah, dan kondisi keluarga korban ialah berasal dari keluarga dengan orang tua yang bercerai (Broken Home). Sejalan dengan yang dikatakan oleh Hurairah (2006) menyatakan bahwa salah satu faktor yang menyebabkan terjadinya kekerasan seksual terhadap anak adalah perceraian orang tua (Broken Home) yang berdampak buruk pada anak seperti penelantaran anak.

Kasus kekerasan seksual yang terjadi pada anak tentu saja akan menimbulkan dampak yang tidak baik terhadap anak diantaranya yaitu dampak psikis, psikologis, dan sosial (Subidia \& Raijaya, 2016). Dari semua dampak yang ditimbulkan karena kejadian kekerasan seksual pada anak tentu saja akan mengganggu pertumbuhan dan perkembangan mereka, anak akan merasa trauma akibat kejadian yang menimpanya. Untuk itu pendampingan terhadap anak sangatlah penting untuk pencegahan terjadinya kekerasan seksual pada anak, wadah pertama yang dapat membentuk pola kepribadian anak adalah keluarga (orang tua).

\section{METODE PENELITIAN}

Bentuk penelitian ini adalah penelitan kuantitatif deskriptif. Penelitian kuantitatif deskriptif bertujuan untuk memaparkan, menjelaskan secara detail, dan merangkum berbagai kondisi atau fenomena yang ada dikalangan masyarakat yang sesuai dengan objek penelitian berdasarkan fakta yang terjadi dilapangan. Penelitian ini memfokuskan pada suatu unit tertentu dari berbagai variabel, dari ciri yang sedemikian rupa, memungkinkan studi ini akan amat mendalam dan menusuk sesuai dengan sasaran penelitian (Bungin, 2006 ).

Variabel merupakan suatu konsep yang memiliki nilai-nilai berupa kuantitatif (angka) maupun kualitatif (kalimat) yang 
nilainya dapat berubah-ubah (Siregar, 2010). Berdasarkan pada judul penelitian ini yaitu tentang gambaran latar belakang keluarga korban kekerasan seksual, oleh karena itu identifikasi variabel hanya menggunakan satu variabel yaitu variabel kekerasan seksual.

Teknik pengambilan sampel pada penelitian ini menggunakan teknik purposive sampling. purposive sampling merupakan teknik pengambilan sampel yang menggunakan kriteria yang sejalan dengan tujuan penelitian (Siregar, 2013). Sampel dalam Penelitian ini yaitu terdiri dari 52 orang tua yang anaknya menjadi korban kekerasan seksual yang ada di Kab. Siak Sri Indrapura.

Instrumen dalam penelitian ini yaitu menggunakan angket mengenai latar belakang keluarga korban kekerasan seksual dan wawancara. Berikut ini adalah blue print angket latar belakang keluarga:

Tabel 1. Blue Print Angket Latar Belakang Keluarga Korban Kekerasan Seksual

\begin{tabular}{|c|c|c|c|}
\hline Aspek & Indikator & Aitem & Jumlah Aitem \\
\hline Kemiskinan & $\begin{array}{l}\text { Jenis pekerjaan, } \\
\text { jumlah pendapatan, } \\
\text { kecukupan } \\
\text { kebutuhan, dan } \\
\text { tempat tinggal. }\end{array}$ & $1,2,3,16$ & 4 \\
\hline Broken Home & $\begin{array}{l}\text { Status pernikahan, } \\
\text { hubungan dengan } \\
\text { keluarga, } \\
\text { menikah. }\end{array}$ & $4,5,18$ & 3 \\
\hline $\begin{array}{l}\text { Pendidikan orang } \\
\text { Tua }\end{array}$ & $\begin{array}{l}\text { Pengajaran } \\
\text { terhadap anak } \\
\text { kurang, jenjang } \\
\text { pendidikan rendah. }\end{array}$ & 6 & 1 \\
\hline Pola asuh permisif & $\begin{array}{l}\text { Acuh dan tidak } \\
\text { peduli, } \\
\text { pada anak rendah }\end{array}$ & 8,9 & 2 \\
\hline Pola asuh otoriter & $\begin{array}{l}\text { Mengekang anak, } \\
\text { menghukum, } \\
\text { kontrol } \\
\text { tinggi }\end{array}$ & $10,11,13$ & 3 \\
\hline $\begin{array}{l}\text { Pola asuh } \\
\text { Demokratif }\end{array}$ & $\begin{array}{l}\text { Menghargai } \\
\text { pendapat anak, } \\
\text { bersikap hangat }\end{array}$ & 7,12 & 2 \\
\hline $\begin{array}{l}\text { Kelalaian orang } \\
\text { Tua }\end{array}$ & $\begin{array}{l}\text { Pengawasan } \\
\text { terhadap anak, } \\
\text { kedekaan dengan } \\
\text { anak }\end{array}$ & $14,15,17$ & 3 \\
\hline Jumlah & & 18 & 18 \\
\hline
\end{tabular}




\section{HASIL DAN PEMBAHASAN}

Berdasarkan dari hasil penelitian dapat dilihat dari aspek tingkat ekonomi pada penelitian ini rata-rata responden bekerja sebagai buruh atau petani dengan jumlah penghasilan 1,5 sampai 2,5 juta rupiah namun tidak terlalu jauh selisihnya dengan jumlah responden yang memiliki pendapatan 1,5 juta rupiah. Selain itu, dengan jumlah penghasilan yang didapat responden merasa masih kurang mencukupi kebutuhan. Dan rata-rata responden bertempat tinggal dirumah sendiri. Dapat disimpulkan bahwa tingkat ekonomi responden dalam penelitian ini pada kategori rendah. Oleh karena hal tersebut kebutuhan anak yang masih kurang terpenuhi dapat membuat si anak lebih mudah dipengaruhi untuk dijadikan sasaran kejahatan seksual oleh pelaku kejahatan dengan cara mengiming-imingi anak dengan memberikan uang atau mainan atau sejenisnya yang membuat anak terhibur dan dengan mudah pelaku melancarkan perbuatan jahat tersebut. Hal itu didukung oleh hasil penelitian yang dilakukan oleh Fajriani dan Bahri (2015) mengatakan bahwa salah satu faktor penyebab terjadinya kekerasan seksual terhadap anak adalah faktor ekonomi yang rendah karena kecukupan kebutuhan anak yang belum terpenuhi, korban dengan mudah mengikuti keinginan pelaku kejahatan seksual dengan mengimingimingi korban dengan memberi uang atau benda lainnya. Pelaku mengiming-imingi korban dengan memberikan sejumlah uang atau membelikan apa yang diinginkan anak dan dengan mudah pelaku melakukan kejahatannya kepada korban (Humairah, dkk 2015).

Selanjutnya pada aspek broken home (keluarga tidak utuh), Berdasarkan hasil penelitian dapat dilihat bahwa kondisi hubungan keluarga pada responden dalam penelitian ini dapat dikatakan masih baik, dengan rata-rata tertinggi berada pada status pernikahan yang masih utuh, hubungan dengan keluarga yang masih terjalin dengan baik, dan usia pernikahan yang cukup lama yaitu 10-20 tahun. Dapat disimpulkan bahwa pada subjek penelitian ini ditinjau dari aspek keluarga broken home, anak yang menjadi korban kekerasan seksual bukan dari keluarga yang broken home karena keluarga korban masih utuh dan baik-baik saja. Faktor penyebab kekerasan seksual bukan hanya dari keluarga yang tidak utuh (broken home) akan tetapi penyebab kekerasan seksual pada anak juga dapat disebabkan oleh kepercayaan sosial yang tinggi akibat kohesi sosial di lingkungan keluarga menjadi pelemah pengasuhan dan pengawasan orang tua terhadap anak (Fitriyani, 2017).

Kemudian pada aspek tingkat pendidikan orang tua, dapat dilihat bahwa tingkat pendidikan orang tua pada penelitian ini secara umum adalah lulusan SMA, dan dapat dikatakan tingkat pendidikan responden dalam penelitian ini pada kategori menengah. Kekerasan seksual tidak hanya disebabkan oleh pendidikan orang tua yang rendah, akan tetapi kekerasan seksual dapat disebabkan oleh faktor lain yaitu anak dianggap pada posisi yang lebih lemah dan tidak berdaya, moralitas masyarakat terhadap kekerasan seksual rendah, kontrol dan kesadaran orang tua terhadap tindak kejahatan pada anak yang rendah (Hertinjung, 2009). Hal itu juga didukung oleh peneltian Sitompul (2015) kekerasan seksual pada anak disebabkan karena anak-anak mudah untuk diancam dan dilukai oleh pelaku kekerasan seksual mengingat anak-anak tidak mampu melawan atau menjaga dirinya terhadap bahaya yang menimpanya

Berikutnya pada aspek kelalaian orang tua, berdasarkan hasil penelitian dapat dilihat bahwa pada aspek kelalaian orang tua menunjukkan pengawasan orang tua terhadap anak ketika anak pergi dan keluar bersama temannya respon orang tua ialah mengatakan menanyakan pergi kemana dan membolehkan keluar, orang tua tidak mengawasi dan membatasi kapan anak harus pulang. Selain itu, durasi interaksi antar orang tua dan anak sekitar 15 menit. Kelalaian orang tua dapat menyebabkan anak menjadi korban kekerasan seksual karena kurangnya pengawasan dan kedekatan antara orang tua dan anak, hal tersebut didukung hasil penelitian yang 
dilakukan oleh Ratri dan Agustina (2018) mengatakan bahwa kekerasan seksual dapat terjadi oleh faktor kelalaian orang tua yaitu kurangnya kedekatan antara orang tua dengan anak dan kurangnya pengawasan tentang pergaulan anak yang membuat subjek menjadi korban kekerasan seksual. Hal itu juga didukung oleh hasil penelitian Murdiyanto (2017) mengatakan bahwa kekerasan seksual dapat terjadi karena kurangnya pengawasan orang tua terhadap anak dan interaksi antara orang tua dengan anak yang tidak maksimal dalam arti kurang atau bahkan jarang sekali tejadi, oleh sebab itu pengawasan orang tua terhadap anak akan menjadi lemah.

Selanjutnya pada aspek pola asuh, berdasarkan hasil penelitian dapat dilihat bahwa orang tua membimbing anak dengan baik dan tidak suka menghukum anak sembarangan seperti memukul dan membentak. Selain itu, orang tua juga sudah perhatian terhadap anaknya dapat dilihat dari ketika anaknya ada acara di sekolah maka orang tua menghadiri acara anaknya, dan anak lebih dekat dengan ibu dibandingkan dengan temannya. Penyebab kekerasan seksual terjadi tidak hanya dari pola asuh orang tua saja, akan tetapi kekerasan seksual pada anak dapat terjadi oleh beberapa faktor diantaranya yaitu kesenjangan sosial dan ketidakmampuan keluarga memenuhi kebutuhan ekonomi, menyebabkan orang tua sibuk bekerja sehingga tidak bisa selalu mengawasi anak (Fajriansyah, 2019).

\section{SIMPULAN}

Berdasarkan hasil analisis dan pembahasan dapat disimpulkan bahwa secara umum gambaran latar belakang keluarga korban kekerasan seksual pada penelitian ini yaitu berasal dari keluarga dengan tingkat ekonomi rendah, kelalaian orang tua terhadap anaknya yang berupa pengawasan dan komunikasi yang kurang antara orang tua dan anak.

\section{DAFTAR PUSTAKA}

Bungin, B. (2006). Metodologi Penelitian Kuantitatif. Jakarta: Kencana.
Fajriani \& Bahri,S. (2015). Suatu Kajian Awal Terhadap Tingkat Pelecehan Seksual Di Aceh. Jurnal Pencerahan, 9(1), 50-65.

Fajriansyah, R. (2019). Analisis Dampak Kekerasan Sesksual Terhadap Anak Di Kecamatan Pauh Kota Padang, Jurnal Ensiklopediaku, 1(2), 200-205.

Fuadi, M. Anwar. (2011). Dinamika Psikologis Kekerasan Seksual: Sebuah Studi Fenomenologis. Psikoislamika, Jurnal Psikologi Islam, 8(2), 191-208.

Fitriyani, A. (2017). Disfungsi Keluarga Dalam Kekerasan Seksual Pada Anak Dan Remaja: Studi Kasus Pada Korban Dan Pelaku Kekerasan Seksual Di Garut.

Hertinjung, W. S. (2009). The Dynamic Of Causes Of Child Sexual Abuse Based On Availability Of Personal Space And Privacy.

Hidayati, N. (2014). Perlindungan Anak Terhadap Kejahatan Kekerasan Seksual (Pedofilia). Jurnal Pengembangan Humaniora, 14(1), 6873.

Hurairah, A. (2006). Kekerasan Terhadap Anak. Bandung: Nuasa Press.

Humairah, Dkk. (2015). Kekerasan Seksual Pada Anak: Telaah Relasi Pelaku Korban Dan Kerentanan Pada Anak, Jurnal Psikoislamika, 12(2), 5-10.

Kurniasari, A. (2016). Analysis Of Risk Factors Among Children To Become Victims Of Sexual Exploitation In Surabaya City, Jurnal Sosio Konsepsia,5(3), 113-134.

Murdiyanto. (2017). Sexual Violation Toward Children, Jurnal PKS, 16(1), 7588.

Ratri, K. A \& Agustina, W. P. (2018). Analisis Tindak Kekerasan Seksual Pada Anak Sekolah Dasar. Jurnal Kajian Teori Dan Praktik Pendidikan, 3(2), 151-155.

Subidia, K \& Raijaya, M. (2017). FaktorFaktor Sosial Ekonomi Penyebab Terjadinya Kasus Pelecehan Seksual Pada Anak Di Kota Denpasar, 8(1), 917.

Siregar, S. (2013). Metode Penelitian Kuantitatif. Jakarta: Kencana. 
Sitompul, H. (2015). Kajian Hukum Tentang Tindak Kekerasan Seksual Terhadap Anak Di Indonesia, Jurnal Lex Crimen, 4(1), 46-56

UPT P2TP2A Provinsi Riau. (2019). Data kekerasan di provinsi Riau tahun 2019.

World Health Organization. (2002). World Report On Violence And Health.

Geneva: WHO.
Https://Www.Kpai.Go.Id-KPAl-SebutPelanggaran-Hak-Anak-TerusMeningkat.

Diakses Pada Tanggal 8 Februari 2020, Pukul 20:53 WIB.

Https://M.Liputan6.Com-BPS:PenghasilanRp-1,9-Juta-Perbulan-MasukKategoriWarga-Miskin. Diakses Pada Tanggal 20 Februari 2020, Pukul 18:14 WIB 
Volume 1, No.1, Juni 2021 